\title{
Perspective Al-Qur'an and Biology in Human Creation
}

\author{
F D Agustina ${ }^{1}, \mathrm{M} \mathrm{N} \mathrm{Huda}^{2}$ \\ ${ }^{1}$ Islamic Building School of Jagad Alimussirry Surabaya, Indonesia \\ ${ }^{2}$ Tarbiyah Department, Universitas Islam Negeri Sunan Ampel Surabaya \\ Email: fitriagustina040898@gmail.com
}

\begin{abstract}
Allah has ordered humans to pay attention to human creation, but the lack of human knowledge and understanding of the correlation of the Qur'an and Biology related to the process of human creation is one of the factors causing a person's lack of faith. This study aims to determine the creation of humans based on the Qur'an that has links with Biological Sciences. This research is library research whose information is obtained through the Qur'an, scientific articles, and biology books. The results of this study are the creation of humans based on the perspective of biology is that God created humans from the fusion of sperm cells and ovum cells. Sperm and ovum cells are part of the human body which are the same components of the human body as components of the soil that have been processed by plants through photosynthesis. Humans were created by God from the fusion of sperm cells from the testes and ovum cells from the ovaries, where the development of the two reproductive organs grows between the sulbi bone (backbone) and breast bone. And humans will be resurrected by God through human bones that are still left in the soil, namely the tailbone.
\end{abstract}

Keywords: Human Creation, Al-Qur'an, Biology

\section{INTRODUCTION}

Disasters are natural phenomena that can be experienced by all living things, especially humans, where disasters are given by God to humans as a result of the environmental damage behavior done by humans themselves. According to the religious point of view that disaster is a test for humans which is at least in the following verse: "Why when a disaster strikes (in the Battle of Uhud), even though you have defeated your enemy twice (in the Battle of Badr), you say, 'Where did it come from? Iin the form of defeat)? Say, 'That (comes from) yourself.' Allah is the Almighty over all things,"(Surah Ali Imran: 165). Disasters experienced by humans are also torture for humans themselves according to the following verse: "Unbelievers are always struck by disasters because their actions or disasters occur near their homes so that God's promises are proven. God does not break promises, "(Surat ar-Ra'd: 31).

The verses above state that the indicators of a disaster that become the test and the disaster which becomes torture are very clear. If the disaster is caused due to an unintentional mistake, then the disaster is a test for the culprit, to then measure the level of faith. Conversely, if the disaster is caused by immoral behavior, wrongdoing, and intentional disbelief, then the disaster becomes torture for humans to remind people of mistakes that have been made and correct their mistakes by increasing their faith [1].

All over the world today has experienced a disaster that caused fatalities due to the Covid19 outbreak caused by a virus called SARSCoV2 or better known as the Corona Virus. The virus that attacks the human respiratory 
system has infected 9,333,640 people worldwide [2]. The virus is one of the living creatures that has been created by God to provide testing or torture for all humans on earth. These natural phenomena which prove that the low level of human faith in God.

Islam has taught all Muslims to increase one's faith in Allah in various ways, namely avoiding prohibitions and carrying out God's commands. God has ordered humans to pay attention to their creation so that humans will never forget the origin of their creation by God. "Then consider how Allah created (man) from the beginning" (al-Ankabut [29]: 20), "Man should pay attention to what he was created from?" (At-Tariq [86]: 5).

Humans are a creature of millions of creatures on this earth who were created with the perfection that exceeds the creation of other living creatures that were created by God. One difference between humans and other living creatures is that humans were created with high intelligence [3]. The ability to think of humans at this time has even brought humans to modern civilization with a variety of advanced technologies that increasingly help humans and the ability to think, the more people are interested in researching the process of human creation itself.

Human creation is the subject of the Qur'an which is the most important source of knowledge and knowledge. Al-Qur'an is a book that has great attention to the activities of thought and science. Islam requires its adherents to study and develop knowledge. Science possessed by humans continues to develop along with the times. Knowledge of the results of human thought from the results of scientific research is used to probe the secrets of nature to understand the power of God which was first contained in the Qur'an [4]. Al-Qur'an is the word of God as a motivator and builder of scientific awareness in every Muslim to think, understand, and use his mind. Al-Qur'an is a book of guidance so that humans can interpret various natural events as the guidance given by God, therefore the Qur'an can be a reference in explaining scientific theories, especially biology [5].

Biology is the study of related interactions between living things and the environment that living things inhabit, namely nature. The object of biological research in nature and nature's inhabitants, namely living things which are classified into 6 kingdoms namely Animalia, Plantae, Protista, Function, Eubacteria, and Archaebacteria [6]. Examples of living things that are classified as kingdom Animalia are humans, so biology studies in detail based on human anatomy and physiology, as well as the origin of human creation. While Allah is the creator of every creature in this world, that is what Allah proclaims through His verses in the Qur'an [7].

One of the relations of biology with the Qur'an related to human creation is based on QSAl Mu'minun: 12-14:

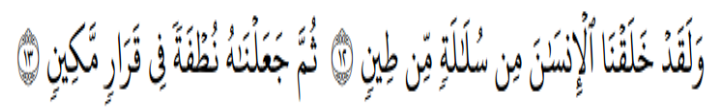

"And indeed We have created man from an essence (derived) from the land (12). Then We make the essence of semen (stored) in a firm place (womb) (13). Then we made the semen of a clot of blood, then a lump of blood. We made a lump of meat, and a lump of flesh We made bones, then we wrapped the bones with flesh. Then We made him another (shaped) being. Then Blessed be Allah, the Best Creator (14). " (QS Al Mu'minun: 12-14).

Based on that verse, it implies the process of human creation in the realm of ham (pregnancy period), which begins with Tualatin min thin (earth quintessence), then becomes a nutfah, then, alaqah (blood clot), then mugdhotan, then izaman, lahman and kholqan. Human creation comes from the essence of soil starch, which is the core of substances in the ovum and sperm. Egg cells that have been fertilized by sperm become zygotes or called germplasm. The zygote 
moves through the fallopian tubes toward the uterus. After sticking to the uterine wall, it turns into alaqah. The term alaqah can be interpreted as something that hangs. The next process, turns into mugdhotan which is shaped like a piece of meat, then grows bones (izaman) bones wrapped in meat (lahman), then becomes kholqan akhar (embryo) [8].

Based on the description above, the researcher will discuss the value of human creation based on the perspective of the Qur'an and Biology. Human creation is ideal when the science of biology as a real proof of the power of Allah from the Qur'an which has the final, definite, and absolute truth. So that we can get to know the Creator, Allah, and increase our devotion, faith, worship, and obedience to God because it will be difficult for someone to become a man of faith and pious if he does not know who their Rabb is. When someone activates (knows) Allah, then there will be mahabah (love) for Allah. Indeed the true purpose of man was created to carry out worship to God and the obligation is to obey Him by the basic nature (fitrah) that God has created for him [9].

\section{METHOD}

This research uses the type of library research which is a series of activities relating to the method of library data collection [10]. Information on this research was obtained from the Qur'an, scientific articles, and Biology books according to Campbell et al. (2008) volumes 1 and 3. The library researches the way to obtain information data by placing existing facilities in libraries such as books, magazines, documents, notes of historical stories, or pure research related to the object of research [11].

\section{RESULT AND DISCUSSION}

With the rapid development of the age, many of the latest discoveries in biological science can explain the word of God. One of them is the creation of man himself, so much so that the correlation between the Qur'an and the biological sciences is found. Human creation based on the Qur'anic perspective and Biological Sciences will be divided into two points: human creation from the soil and human creation from the bone. The distribution of each point will be described in more detail below.

\section{A. The Creation of Man From the Land} Of the Qur'an which is the word of God which is eternal and surely true gives man knowledge of his creation originating in the land. God has explained the creation of man from the ground in QS. Tha Ha (20): 55, QS. Al-Insan (76) verse 2, and QS. Al- Mu'minun (23): 12-13. The following is the third meaning of the letter explaining the creation of man in the Qur'an and its corollary to the biological sciences related to the creation of man from the ground.

Allah Almighty says in QS. Tha Ha (20): 55

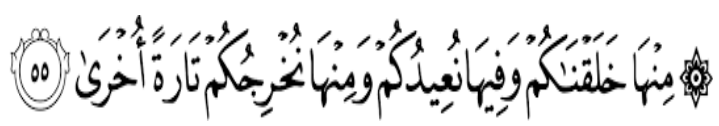

"From this (earth) We made you and to Him, we will restore you and from it, we will bring you forth at another time."

Based on QS. Tha Ha (20) verse 55 states that Allah Almighty created man from the soil of the earth and that God will bring man back to earth. Human creation originated from the land further described in QS. Al-Mu'minun (23) verse 12 states that God created man from the starch that comes from the ground and that God created the offspring of man from a drop of the sperm / male semen that came out of the spinal cord, and fixed it in the womb of women [ 13]. The character referred to in the verse is an element of similarity found inland and man [14].

Allah Almighty says in QS. Al-Mu'minun (23): 12

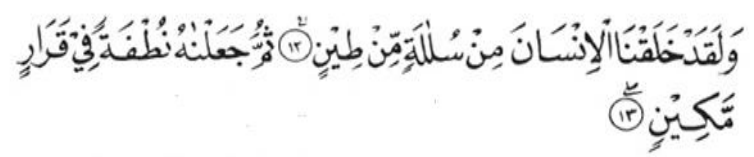


"And verily We have created man from the earth. And then We created her offspring from a drop of nuthfah, that is, semen from their bones, and settled in the womb of women."

Another opinion says that sulalah min tin in the verse is male sperm and female ovum derived from food consumed by humans. While the food comes from the ground [15]. That is following the verses of the Qur'an in the QS. Al-Insan (76) verse 2 that Allah said that humans were created from mixed semen. The semen is produced from men and women. The process is that men produce sperm while women are known as ova. So that if the sperm contained in a male and female are fused, a fetus will form [13].

Allah SWT says in QS. Al-Insan (76) verse 2 reads:

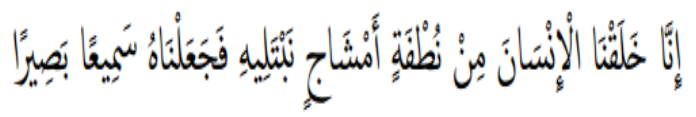

"Indeed, we have created man from a drop of mixed semen that we want to test him (with orders and prohibitions), therefore we made him hear and see".

The knowledge contained in the Qur'an is a science whose truth cannot be doubted because it comes directly from God, especially related to human creation. While humans are one of the living things which is the main object in biology obtained by scientific methods or human reasoning. Therefore there is a correlation between science in the Qur'an and biology.

If in the Qur'an it is stated that humans originate from a meeting between the semen of women and men which is mixed according to biological science, it can be interpreted that human formation from fertilization between the ovum and sperm. Human creation comes from the essence of soil starch, it can be interpreted that the substances in the ovum and sperm are the same as the substances contained in the soil. The fertilized egg cell by sperm becomes a zygote. The zygote moves through the fallopian tube to the uterus after attaching to the uterine wall, then the zygote will develop into a human [8].

Semen is composed of sperm and fluid originating from the glands of the male reproductive system (prostate gland, seminal vesica, and bulbonalis gland) called plasma seminal / plasma semen. Seminal plasma is composed of protein, ascorbic acid, sodium, potassium, and calcium [13]. While sperm (singular: spermatozoa) are cells composed of cell organelles with the chemical composition of glucose (monomers / smallest molecules of carbohydrates), amino acids (monomers from proteins), and lipids (monomers from fats). Proof which states that cell organelles which are owned by spermatozoa cells consisting of glucose, amino acids, and lipids are one of the spermatozoa cell organelles to be described are plasma membranes [16].

Cell membranes are composed of integral proteins, glycolipids, glycoproteins, cholesterol, phospholipids. Integral protein (composed of amino acids), glycoproteins (glucose molecules that bind to proteins), glycolipids (glucose molecules that bind to lipids), cholesterol (composed of lipids), carbohydrates (composed of glucose), phospholipids (fat layers that bind to lipids) lipids / fat). Therefore it can be concluded that sperm is composed of 3 basic organic elements namely glucose / carbohydrate, amino acids / protein, and lipids / fat. The three molecules are composed of mostly carbon, oxygen, hydrogen, and nitrogen atoms [17]

Protein, carbohydrates, and fats which are organic compounds and inorganic compounds that make up plasma semen in semen / human semen are derived from plant products (organic compounds) that are consumed by humans every day, for example fruits, vegetables, tubers, etc. [14].Inorganic compounds contained in the soil are called soil mineral elements consisting of macro and micro, which will be contained in Figure 3.3. Examples of micro (atomic) and macro constituents of soil are oxygen, calcium, 
hydrogen, phosphorus, sulfur, carbon, magnesium, botassium, nitrogen, iron, etc. [17].

Nutrients in the soil will be changed by plants through a process that can convert inorganic compounds into organic compounds by involving sunlight and chlorophyll called photosynthesis. Organic compounds (carbohydrates, proteins, and fats) that have been consumed by humans enter the human digestive system. The digestive system will convert complex compounds of carbohydrates, proteins, and fats) into simpler compounds (glucose, amino acids, and lipids / fatty acids). These simpler compounds will be used as ingredients for the formation of semen [17]. Therefore semen has a component derived from soil starch / mineral soil extracts. Semen is one component in the human body (organic compounds), So that the human body also has the same components as the components that make up semen, then it can be concluded that all the constituents of the human body have the same components as the soil constituents [14]. Therefore the description above is by the verses of the Qur'an that humans originate from the essence of soil.

Allah will return people to the ground, then Allah will bring people out of the ground on the Day of Judgment (resurrection). Based on the four verses of the Qur'an above states that God will return humans to the ground. At the end of human life will experience death, in Islam our death will be buried in the ground, so that humans will be returned to the ground. According to biological science that humans are composed of organic compounds (glucose, protein, and lipids). And soils also contain microorganisms such as bacteria and fungi that act as decomposers or decomposers. Microorganisms remodel organic compounds found in living things that have died one of them is a deceased human inorganic compounds that make up nutrients in the soil such as oxygen, calcium, hydrogen, phosphorus, sulfur, carbon, magnesium, botasum, nitrogen, iron, etc. [17].
Based on the explanation above, it can be seen that the constituent components of the soil are the same as the constituent components of semen and other human bodies, namely organic compounds (carbohydrates, proteins, and fats) so that it is by the Qur'an that humans originate from soil starch extracts. Humans who have died will be decomposed by decomposers in the soil to become nutrients contained in the soil. Therefore there is a correlation between the verses in the Qur'an with biology related to human creation derived from soil starch extract.

\section{B. Human Creation and Human} Resurrection From Sulfur Bones

Sulbi bone in the language means coarse, strong (ghalidz), hard (syadid). Sulbi is the spine from the top to the bottom [3]. According to the Qur'an surah ath-Thariq verse 7, Allah mentions the spinal cord with the meaning of the spine/back, while in the hadith of the Messenger of Allah, the spinal cord means tail bone. The following will be explained about the creation of man and the resurrection of man from the bone.

\section{Human Creation Of Sulbite (Backbone) And Chest}

God in the At-Thariq Letter verses 5-7 read:

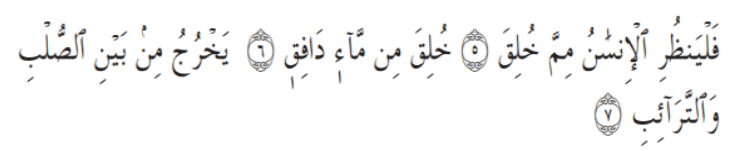

"Let man look at what he has created. He (man) was created out of the water, which came out between the spine and the chest."

Man has to pay attention to what he was created for and where he will return. In that verse, God explains that man is created from the water that is emitted, which comes out of the spinal cord and the breast. She is made from water that emanates from the male spinal cord, from her backbone, and the female upper chest bones [4].

According to the Word of God in the letter, At-Thoriq explains that man was created from the water emitted and came out between the 
bone and the chest. The word "out" does not mean that it was produced. In the phrase "between the bone and the breast," it also emphasizes that semen does not come from the bone, but rather. So it would be incorrect to interpret the semen as it is produced or produced from the bone. Allah Almighty uses the best language to teach His word to His creatures so that it is easier to understand.

According to Dr. Zakir Naik in his book, Qur'an and Modern Science explains that in the early development of the human reproductive organs of the testes in men and ovaries in women occur around the kidneys, between the spinal cord, the eleventh rib and the twelfth. As its development, the formation of the testes and ovaries will go down. The ovary (female egg) stops in the pelvis, while the testes in men descend towards the scrotum. After the development has decreased, the testes and ovaries still get a supply of nerves that are between the spine and sternum [18].

Dr. Zakir Naik in his book Qur'an and Modern Science explains that the sulbi bone is a place where blood vessels that meet the nutritional and oxygen needs of the testes and ovaries, which lie between the sulbi bone and breast bone, are vascular artery (blood vessel system) and ovary artery (blood vessels that supply oxygenated blood to the ovaries in women) starts from one place between the sulbi bone and the sternum [18]. So that means that semen is not produced by sulbi bone but sulbi bone is a place where blood vessels that supply oxygen and nutrients to the testicular and ovarian cells lie between the sulbi bone and breast bone [4].

Embryology specialists as quoted by Dr. Muhammad Ali al-Barr in a long study was able to prove that all parts of the human body grew from a very small band called the "first band or baseband" or primary band consisting of multipotential primary cell cells (pluripotent primitive streak cells). This primary band is created by God's power on the fifteenth day after ovum fertilization and implantation in the uterine wall. Cells in the primary band have features with an extraordinary ability to do cell division quickly which will form tissues, then form organs of the human body, beginning with the nervous system and the formation of the spine [4].

2. Human Resurrection on the Day of Judgment with Sulbi Bone (Coccyx)

Sulbi bones in several hadiths of the Prophet mentioned that humans will be resurrected on the Day of Judgment through sulbi bones that will not be damaged when decomposed by decomposers (bacteria or fungi) in the soil [19].

One of the Prophet's hadiths about the tailbone is:

$$
\text { كل ابن ادم يأ كله التراب إلا عجب الذنب منه خلق و فيه يركب }
$$

"All (part of the body) of Adam's child will be eaten by the earth except the tailbone. It was from him that he was created and with it he was reassembled" (HR. Muslim).

Abu Hurairah added: There is no part of the human body except it will perish, except for only one bone, namely the tailbone. Out of it humans will be assembled on the Day of Resurrection [4]. Dr. Zaghul an-Najjar stated in his book, Al-I'jaz 'Ilmi fi as-Sunnah anNabawiyyah, that the tailbone is called the base (base seed) which is the point of human awakening, because the tailbone will remain intact even though the entire body has been destroyed melting is broken down by decomposers in the ground, to then become "seeds" and revive humans on the day of the resurrection. This is in accordance with the word of God in Surah Yasin 78-79 as follows:

Allah says in Surah Yasin verses 78-79 reads:

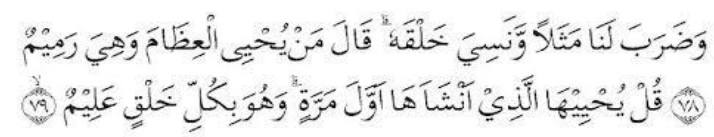

"And he (the ungodly) made for us a parable; while he forgets his (self) events; he said: 'Who can give life to bones, even though they 
have been destroyed?' Say (Prophet Muhammad): "He will be made alive by the One who created him the first time. And He is All-Knowing of all creation. " (QS: Yasin Verses 78-79).

Based on the Word of God in the Yasin verses 78-79 states that only God is able to revive humans on the Day of Resurrection or Judgment Day later. Research has proven that this primary band shrinks until it sinks into the base of the tugging / sulbi bone at the tip of the spine which is meant by the tailbone in the hadith of the Prophet Muhammad. When someone dies, then all the organs of the body will be damaged and destroyed by breaking down by bacteria and fungi except the tail bone which is mentioned by some of the hadiths of the Prophet Muhammad as a seed of human re-creation on the Day of Resurrection [4].

Allah SWT says in QS. Qaf verse 4 reads:

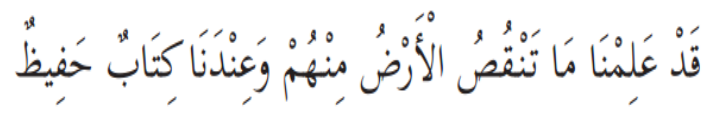

"Indeed, we have known what the earth destroyed from (their bodies), and on Our side to there is a book that preserves (records).

Based on this holy verse, it can be seen that the human body will be destroyed by the earth. This is by the science of biology that the human body contains organic compounds. When humans die, they will be buried in the soil, there is a decomposer (microorganisms/bacteria and fungi). The microorganisms will break down organic compounds into inorganic compounds. These inorganic compounds are the basic components of soil [17].

Therefore, all human body has nothing left but one important component. Rasulullah SAW also explained what was left of the human body after experiencing decomposition, namely the tailbone. The tailbone is the starting point for human reassembly on the day of the resurrection. Therefore, it can be said that it is the most important component in the human body.

Based on the latest research, as conveyed by Jamil Zaini, Cubic Southeast Asian Trainer Jakarta when filling the breaking fast together at al Azhar-Solo Baru with the headline, "Inspiring Day, Inspiring The Spirit of Life", this tailbone records all the actions of Adam's children, from birth to death. He recorded all their good and bad deeds. And their actions will affect the condition of the tailbone. Clean white or dirty black. The more positive energy or goodness a person has, the cleaner his tailbone, and the more negative energy or badness a person has, the more black his tailbone is [4].

The specialty of sulbi bones, which is furthermore, sulbi bones also will not be destroyed after being treated by heating, burning to chemical treatment. This is by the hadith of the Messenger of Allāh SA which was reported by Abu Hurairah that the Messenger of Allah said, ,There is a bone in the child of Adam that is not eaten by the ground." They asked, „What is that, $\mathrm{O}$ Messenger of Allah? Bukhari, Nasa 'i, Abu Daud, Ibn Majah, Ahmad in his book al Musnad, and Malik in his book al-Muwaththa') [3].

From the above hadith explains that after human death, all limbs will experience destruction, except for one bone, the sulbi bone. To justify the Prophet's hadith, several researchers have tested the sulbi bone. Among them in 2002, Shaikh Abdul-Majid AzZindani burned 5coccyxto red and black, and he found that only muscle, tissue, and bone marrow cells were burned, while the coccyx (sulbi bone) not affected by the combustion process [20].

A group of Chinese scientists proved in some of their laboratory experiments that the "Agbu $a d h$-Dhanab" section (the final part of the coccyx) could not have been dead. They try to dissolve it chemically in the strongest acid, through combustion, pounding, and by giving 
various types of radiation. This proves that the hadith of the Prophet Muhammad (PBUH) is true and precedes all scientific experiments 1400 years ago [21].

Based on the description above there is a correlation between human creation from sulbi bones according to the Qur'an and based on research results that humans will be created from semen released from the sulbi bone (backbone) and breast bone. All human bodies that have died will be broken down by decomposer (bacteria and fungi) except sulbi bones (tail bones), where the tail bones will be assembled by Allah SWT, and humans will be resurrected by Allah on the Day of Resurrection.

\section{CONCLUSION}

Human creation based on the perspective of biology is that God created man from the fusion of sperm cells and ovum cells. Sperm and ovum cells are part of the human body which are the same components of the human body as components of the soil that have been processed by plants through photosynthesis. Humans were created by God from the fusion of sperm cells from the testes and ovum cells from the ovaries, where the development of the two reproductive organs grows between the sulbi bone (backbone) and breast bone. And humans will be resurrected by God through human bones that are still left in the soil, namely the tailbone.

\section{REFERENCES}

[1] Hidayatullah, M. S. 2013. Perspektif al-Qur'an tentang Bencana Alam. Hermeunetik. 7(2): 261-278

[2] Fatia, S. N. 2020. Update Virus Corona di Dunia Rabu 24 Juni 2020, Indonesia Catat Kematian Tertinggi di Asia Tenggara. Online. https://www.pikiranrakyat.com/internasional/pr-01575651/updatevirus-corona-di-dunia-rabu-24-juni-2020indonesia-catat-kematian-tertinggi-di-asiatenggara.

[3] Syarifudin. M., Zarkasih., Vebrianto. R., Nurhadi. 2019. Keistimewaan Tulang Sulbi
Berdasarkan Kajian Al-Qur'an Dan Sains. Jurnal Pendidikan Dan Ilmu Sosial. 1(2): 154204. ISSN 2686-2824.

[4] Dewi. N dan Nur., A. 2018. Tulang Sulbi Dalam Tinjauan Tafsir dan Osteologi. Nun: Jurnal Studi Alquran dan Tafsir di Nusantara. 4(2): 79-104.

[5] Zarman, W. (2012). Studi Pengembangan Buku Teks Ilmu Pengetahuan Alam Sekolah Menengah Pertama Berbasis Nilai Keimanan (Disertasi). Bogor: Universitas Ibn Khaldun.

[6] Biggs, A., Hagins, W.C., Kapicka, C., Zike, D., Tallman, K.G., Rillero, P. 2004. Biology: The Dynamics of life. New York: McGrawHill Companies, Inc.

[7] Al-Qaththan, S. M. (2005). Pengantar Studi Ilmu Al-Qur'an. Jakarta: Pustaka Al Kautsar.

[8] Silvia. 2017. Pengembangan Buku Ajar Biologi Mengintegrasikan Imtaq Pada Materi Sistem Reproduksi. Surabaya: Skripsi Universitas Negeri Surabaya.

[9] Al-Attas, S. M. N. (2010). Islam dan Sekularisme. Bandung: Institut Pemikiran Islam dan Pembangunan Insan.

[10] Mahmud. 2011. Metode Penelitian Pendidikan, Bandung: Pustaka Setia

[11] Sholeh, Abdul Rahman. 2005. Pendidikan Agama dan Pengembangn untuk Bangsa. Jakarta: PT. Raja Grafindo Persada.

[12] Subagiya. B., Hafidhuddin. D., Alim. A. Internalisasi Nilai Penciptaan Manusia Dalam Al-Qur'an Dalam Pengajaran Sains Biologi. Tawazun: Jurnal Pendidikan Islam. 11(2): 190-210. e-ISSN: 2654-5845.

[13] Amin. 2019. Keilmiahan Ayat-Ayat Penciptaan Manusia. El-'Umdah. 2(2): 133170.

[14] Wahid, M, A. 2019. Teori Mengenai Penciptaan Manusia dalam Hadis Nabi: Kajian Ma'anil Hadis. Tahdis. 10(2): 173-189.

[15] Taufiq, Muhammad Izzudin. 2006. Dalil Anfus, Al-Qur'an dan Embriologi: AyatAyat Tentang Penciptaan Manusia, terj Muhammad Arifin dkk, Solo: Tiga Serangkai.

[16] Campbell N. A. and J. B. Reece. 2008. Biologi Edisi Kedelapan Jilid III, terj. Wasmen Manalu. Jakarta: Erlangga. 
[17] Campbell N. A. and J. B. Reece. 2008. Biologi Edisi Kedelapan Jilid I, terj. Wasmen Manalu. Jakarta: Erlangga.

[18] Naik, Z.A.K. 2016. The Qur"an and Modern Sains : Compatible or Incompatible.Online.https://www/academia.ed u/37157865/Quran_and_Modern_science_By_ Dr._Zakir_Naik

[19] Yahya, H. 2003. Keajaiban Penciptaan Manusia. PT. Global Cipta Publishing. Jakarta.

[20] Al-Karim, S. 2015. Scientific Miracles in the Qur"an About Coccyx or Tailbone. Intl Commission On Scientific Signs In Qur"an and Sunnah. Saudi Arabia.

[21] Endraswara, Suwardi. 2011.Metodologi Penelitian Sastra. Yogyakarta: Tim Redaksi CAPS. 